\title{
Transformation Frequency Increases with Increase in Agitation Rate of Chemostat-cultivated Escherichia coli K12, Strain C-600
}

\author{
By D. A. JOHN WASE, ${ }^{*}$ JAYNE MATTHEWS ${ }^{2}$ AND \\ HIRAN A. M. RATWATTE ${ }^{1}$ \\ ${ }^{1}$ Biochemical Engineering Section, Department of Chemical Engineering, University of \\ Birmingham, PO Box 363, Edgbaston, Birmingham B15 2TT, UK \\ 'Department of Clinical Chemistry, Wolfson Research Laboratories, Queen Elizabeth Medical \\ Centre, Birmingham B15 2TH, UK
}

(Received 29 January 1987; revised 14 May 1987)

\begin{abstract}
The transformation frequency of Escherichia coli C-600, continuously cultivated in a chemostat operated at constant dilution rate, increased with increase in agitation rate (impeller speed). Cell counts at each impeller speed remained approximately constant. The phenomenon correlated with changes in mean cell volume associated with the changes in agitation rate.
\end{abstract}

\section{INTRODUCTION}

Transformation of microbial cells by plasmid DNA is well established, although the exact mechanism of DNA uptake by the cells is not entirely understood. Uptake is closely associated with certain divalent cations such as $\mathrm{Ca}^{2+}$ (Cohen et al., 1972) together with changes in the nature of the outer layers of the cell envelope. For continuously cultivated Escherichia coli, Jones et al. (1981) have shown transformability by plasmid pBR322 DNA to be dependent on the growth rate (dilution rate) and the type of nutrient limitation, and Humphreys et al. (1981) have observed, for $E$. coli grown in batch culture, a direct relationship between transformation frequency and the volume of the microbial cell. Although there are obvious difficulties in extrapolating results of batch culture experiments to continuous culture experiments, this observation provides a possible explanation for the results obtained by Jones et al. (1981), because dilution rate and nutrient limitation variations can effect changes in the cell, and hence change the cell volume (Herbert, 1958).

In a different approach, we have shown for both aerobic and anaerobic continuous culture, at constant dilution rates, that the mean cell volume increases linearly with increase in agitation rate for a range of micro-organisms and conditions (Wase et al., 1982; Wase \& Patel, 1985a). This finding has provided us with a source of microbial cells whose size distribution can be predicted. It was therefore possible to use these cells in transformation experiments and compare the results with those obtained by Jones et al. (1981) and by Humphreys et al. (1981). We describe here experiments in which the cell volume was altered solely by changes in the agitation rate; the dilution rate and the nutritional status remained constant throughout.

\section{METHODS}

Organism and plasmid. E. coli $\mathrm{K} 12$ strain C600 was used in all continuous culture experiments. Plasmid pBR322, which encodes ampicillin and tetracycline resistance, has been described by Bolivar et al. (1977).

Media. L-broth and L-agar (Miller, 1972) containing, where necessary, ampicillin $\left(50 \mu \mathrm{g} \mathrm{ml}^{-1}\right)$ and tetracycline $\left(10 \mu \mathrm{g} \mathrm{ml}^{-1}\right)$ were used for selection of transformants. For continuous cultivation, 1 litre of growth medium (Maniatis et al., 1982) contained $\mathrm{Na}_{2} \mathrm{HPO}_{4}, 6.0 \mathrm{~g} ; \mathrm{K} \mathrm{H}_{2} \mathrm{PO}_{4}, 3.0 \mathrm{~g} ; \mathrm{NaCl}, 0.5 \mathrm{~g} ; \mathrm{NH}_{4} \mathrm{Cl}, 1.0 \mathrm{~g}$. Portions (2 ml) of stock solutions of L-threonine, L-leucine and thiamin. $\mathrm{HCl}$ (each containing $10 \mathrm{mg} \mathrm{ml}^{-1}$ ), were added to give final concentrations of $20 \mu \mathrm{g} \mathrm{ml}^{-1}$. After autoclaving and cooling, the following sterile solutions were added: $1 \mathrm{M}$ $\mathrm{MgSO}_{4}, 2 \cdot 0 \mathrm{ml} ; 20 \%(\mathrm{w} / \mathrm{v})$ glucose, $10 \cdot 0 \mathrm{ml}$ and $1 \mathrm{M}-\mathrm{CaCl}_{2}, 0 \cdot 1 \mathrm{ml}$. 
Fermentation equipment. A Bio-engineering 'Baby' fermenter (Bio-engineering UK), was equipped with a specially fabricated $40 \mathrm{~mm}$ diameter impeller and a load-cell/microprocessor controller to maintain a precisely constant dilution rate as previously described (Wase \& Patel, 1985a).

Transformation. The method is described by Pritchard \& Holland (1985). Transformation frequencies are quoted as the number of transformants per $10^{9}$ cells input. The DNA concentration was more than saturating at $250 \mathrm{ng}$ per $10^{9}$ cells. (Saturating conditions were determined using fermenter-grown cells.)

Culture conditions. The chemostat was inoculated with approximately $10 \mathrm{ml}$ of a culture $(50 \mathrm{ml})$ previously grown in a $250 \mathrm{ml}$ shake flask in the same medium. The chemostat was operated at a dilution rate of precisely $0.4 \mathrm{~h}^{-1}$ after an initial phase of batch operation (approximately $8 \mathrm{~h}$ ). The $\mathrm{pH}$ was maintained at $7.4 \pm 0.03$ by addition of sterile $0.25 \mathrm{M}-\mathrm{NaOH}$ solution. The temperature was maintained at $37 \pm 0.3^{\circ} \mathrm{C}$ and the air flow rate was 1 vol. vol. ${ }^{-1} \mathrm{~min}^{-1}$. The agitation rate was varied from 500 to 2000 r.p.m.

Cell size distribution analysis and total cell counts. A Coulter counter (model $\mathrm{Z}_{\mathrm{B}}$ ) fitted with a $30 \mu \mathrm{m}$ orifice tube was used to obtain total cell counts and an analysis of cell size distribution.

\section{RESULTS AND DISCUSSION}

A plot of typical results of measurements of mean cell volumes and of cell numbers of E. coli C600 against agitation rate showed, as anticipated, that mean cell volume increased linearly with agitation rate; cell count was not affected. These findings are in agreement with previous ones. In particular, the same result was obtained with anaerobic cultures and aerobic cultures and is, therefore, unlikely to be caused by oxygen limitation: in these present experiments, the dissolved oxygen was greater than $50 \%$ of saturation at all agitation rates tested. Fig. $1(a)$ shows that the transformation frequency increased sharply as the impeller speed was increased: because agitation rate (impeller speed) and mean cell volume are linearly related, the latter may be substituted without making a significant difference to the general shape of the graph (Fig. 1b).

These results can be compared with those of Humphreys et al. (1981), who used cells grown in
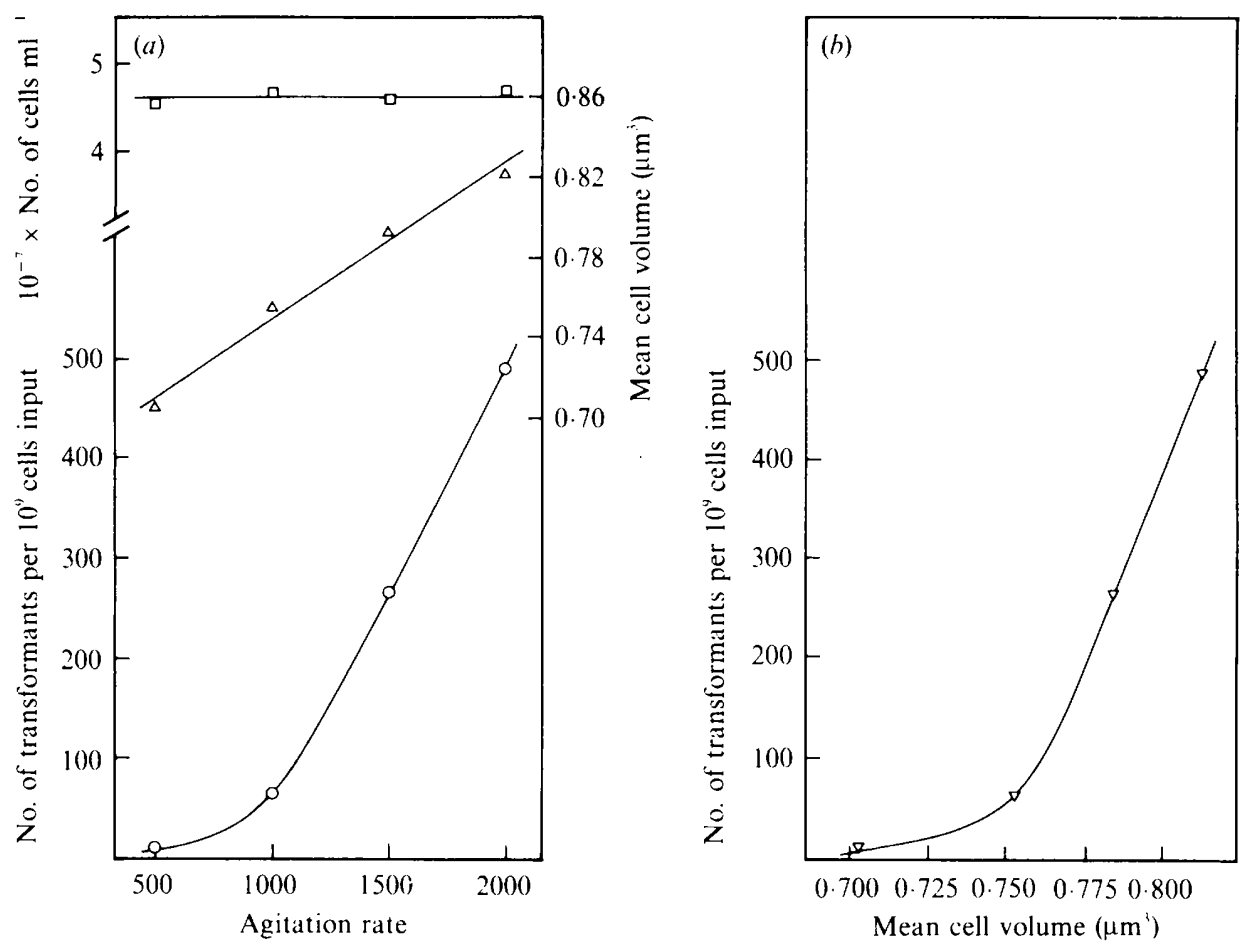

Fig. 1. (a) Effect of changes in agitation rate on the transformation frequency (O), cell number $(\square)$ and mean cell volume $(\triangle)$ of steady-state continuously cultivated $E$. coli $\mathrm{K} 12$, strain C-600. Agitation rates were measured as impeller speeds in the chemostat, and transformation rates are expressed as the number of transformed cells per $10^{9}$ cells input: mean cell volumes were measured using a Coulter counter. (b) Transformation frequency plotted as a function of mean cell volume. 
batch culture and observed that increases in microbial cell volume were accompanied by increases in transformation frequency. However, the composition of batch-cultured cells may vary with the progress of the batch. Jones et al. (1981) used cells grown in continuous culture and showed that the transformation frequency varied as the dilution rate was varied and as the limiting nutrient was varied; but variation of either the dilution rate or the limiting nutrient could lead to changes in the composition as well as in the volume of the microbial cells. Thus these workers were cautious about overemphasizing the role of volume change as the principal causative agent in the effects they observed.

Our method of changing cell volume (changing the agitation rate of an aerobic continuous culture whilst maintaining a constant dilution rate, using a load cell fermenter) involved no changes in nutrient limitation, and therefore made minimal differences to intracellular composition, the principal change being to intracellular water content (Wase \& Patel, 1985a) and solute concentration and composition (Wase \& Ratwatte, 1985). Using this experimental system, we, too, have shown that transformation frequency increased as microbial cell volume increased. We therefore conclude that volume change is a very important causative factor in these effects. Indeed, a parallel can be drawn from work on ultrasonic disintegration of continuously cultivated cells, where it was shown that the disintegration constant depended on the cell volume, irrespective of the nutrient limitation, or of whether the volume changes were effected by changing the agitation rate or the dilution rate (Wase et al., 1982; Patel, 1983; Wase $\&$ Patel, $1985 b$ ). Although the precise reasons for these volume changes remain unknown, they appear to be closely associated with changes in the internal solute concentrations (Wase \& Ratwatte, 1985; D. A. J. Wase \& H. A. M. Ratwatte, unpublished results). The alterations to the cell caused by ions such as $\mathrm{Ca}^{2+}$ are not fully understood, but, as is well known, they increase the frequency of transformation of $E$. coli. Evidently, factors which can change intracellular ionic concentration, already well known to have other very marked effects (Arancia et al., 1980) are of interest with respect to transformation and, therefore, form the basis for our further investigations.

\section{REFERENCES}

Arancia, G., Belli, S., Donelli, G. \& Trovalusci, P. (1980). Ultrastructural changes in Escherichia coli grown in divalent cation-deficient medium. Journal of General Microbiology 119, 155-164.

Bolivar, F., Rodriquez, R. L., Green, P. J., Betlach, M. C., Heyneker, L. \& Boyer, H. W. (1977). Construction and characterization of new cloning vehicles. II. A multipurpose cloning system. Gene 2, 95-113.

Cohen, S. N., Chang, A. C. Y. \& Su, L. H. (1972). Nonchromosomal antibiotic resistance in bacteria: genetic transformation of Escherichia coli by R-factor DNA. Proceedings of the National Academy of Sciences of the United States of America 69, 21102114.

Herbert, D. (1958). Some principles of continuous culture. In Recent Progress in Microbiology, pp. 381397. Stockholm: Almquist \& Wiksell.

Humphreys, G. O., Saunders, J. R., Brown, M. G. M. \& Royle, P. L. (1981). Transformation of Escherichia coli: a consideration of its efficiency at different phases of growth in batch culture. In Transformation 1980, pp. 305-310. Edited by S. Polsinelli \& G. Mazzra. Oxford: Cotswold Press.

Jones, I. M., Primrose, S. B., Robinson, A. \& ELLwOOD, D. C. (1981). Effect of growth rate and nutrient limitation on the transformability of Escherichia coli with plasmid deoxyribonucleic acid. Journal of Bacteriology 146, 841-846.

Pritchard, R. H. \& Holland, I. B. (1985). Basic Cloning Techniques, pp. 36-38. Oxford: Blackwell Scientific Publications.
Maniatis, T., Fritsch, E. F. \& Sambrook, J. (1982). Molecular Cloning, a Laboratory Manual, pp. 68-69. Cold Spring Harbor, NY: Cold Spring Harbor Laboratory.

Miller, J. H. (1972). Experiments in Molecular Genetics, pp. 431 435. Cold Spring Harbor, NY: Cold Spring Harbor Laboratory.

PATEL, Y. R. (1983). Effects of variations in growth conditions on strengths and sizes of continuously cultivated microbial cells. PhD thesis, University of Birmingham, UK.

WASE, D. A. J. \& PAtel, Y. R. (1985a). Variations in the volumes of microbial cells with change in the agitation rates of chemostat cultures. Journal of General Microbiology 131, 725-736.

Wase, D. A. J. \& PATEL, Y. R. (1985 $b$ ). Effect of cell volume on disintegration by ultrasonics. Journal of Chemical Technology and Biotechnology 35B, 165173.

Wase, D. A. J. \& Ratwatte, H. A. M. (1985). Variation of intracellular sodium and potassium concentration with changes in agitation rate for chemostat-cultivated Escherichia coli. Applied Microbiology and Biotechnology 22, 325-328.

Wase, D. A. J., Nesaratnam, S. T. \& Blakebrough, N. (1982). Variation in cell-wall strength of Klebsiella pneumoniae NCTC 418 with change in agitation speed in a chemostat system. Journal of Chemical Technology and Biotechnology 32, 553-555. 